\title{
Cultural Studies and the Neoliberal Imagination ${ }^{1}$
}

$I$.

What remains of the liberal vision of a common public culture in a world of asserted differences? What mechanisms of consenting or dissenting identification sustain a democratic public sphere when politics becomes spectacular? And isn't the representation of publicness always the performance of a division, an exclusion, a minoritization?

In order to put the issues that I think are at stake in these questions as pointedly as I can, let me take as a brief example the rhetoric deployed in Australia at the moment by a politician called Pauline Hanson. Hanson is a right-wing populist in the mould of Le Pen, appealing to a broad working-class and rural constituency who have been damaged, and feel damaged, by the downsizing effects of globalization, by the decline of the rural sector, and by what they perceive to be favorable treatment given to indigenous and immigrant Australians. Her politics of grievance is expressed most economically in two statements: "All Australians should be equal," and "All Australians should speak English." The first of these statements means: "Indigenous people should not claim a separate cultural identity, nor the separate forms of political and economic recognition that might flow from it." The second (which has its American counterparts in, for example, the Californian legislation deeming English to be the sole language of official business) means: "Asian migrants are not welcome in this country because they steal jobs from white people."

These are demands for cultural commonality and for shared civic values; they are at once perfectly reasonable and deeply racist. Note, however, that their illiberal force is expressed in the language of Enlightenment civility: the principles of the equality of citizens, of resistance to privilege, of the rule of law, of civic responsibility. To make this point is not to condemn that language but to say that its uses are always strategic, positional, overdetermined by the secondary codes that translate it for particular knowing audiences.

A similar semantic instability holds for many of the concepts that make up the contemporary discourse of culture and which have rather different meanings in different national contexts. Unlike Australia or Canada, multiculturalism in the United States has to do less with the mediation of diversity within a framework of common citizenship than with the assertion of ethnic or other identity in a pluralized polity. Cultural studies is likewise more closely tied in the United States to a politics of identity understood as a defining difference. The American vernacular use of the concept of liberalism, finally, quite different from its European counterpart,

The Yale Journal of Criticism, volume 12, number 2 (1999): 423-430

(C) 1999 by Yale University and The Johns Hopkins University Press 
aligns it with the state rather than against it and reflects a real ambivalence within the tradition of American political liberalism, which has had to be an ethos at once of free-market anti-communism and, in the absence of a major social-democratic party, of state regulation. To these let me add the notorious and universal incoherence of the concept of "culture" itself, which not only oscillates between normative and inclusive senses but is used to cover very different levels of generality, from whole civilizations to the customs of the local football club; one reason why it is so difficult to define the level at which commonality and difference work is that they do so at many levels.

It is because of these semantic instabilities that I want to avoid casting this paper in terms of the relation of a "common" culture to cultural particularity, since it seems to me that the problem can't properly be posed or resolved in this form. In an important sense there is no conflict here: the tradition of cultural studies in which I work would not necessarily argue that there is or should be no common culture, but it might want to say that it is popular culture, in one form or another, that has assumed that role. This is the position taken, for example, in Paul Willis's oddly neo-Leavisite book Common Culture. ${ }^{2}$ The argument against both the notion of a common culture and those notions of cultural boundedness which underlie a politics of identity, however, is that in complex societies and even perhaps in simple ones people inhabit multiple cultures, and the negotiation of cultural difference is their ordinary business: "commonness" is never a given but is always a goal. It is a limited goal, never a universal one; and however desirable it is as an ideal, it always has the potential to be put to totalitarian uses.

II.

In what follows I seek to displace these questions about culture into questions about the political sphere, and especially the question of the constitution of public space. Taking Lionel Trilling as an exemplary figure in the postwar framing of these questions, I cast my argument in terms of the relation of culture to polity proposed and explored in his work. At the core of Trilling's vision of liberalism's "essential imagination of variousness and possibility" 3 is a matrix of values built around the liberal concept of freedom: values such as openness, complexity, tolerance, irony, and the refusal of dogmatism. These terms, at once aesthetic and civil, constitute an ethos (or what Trilling would call "sentiments") rather than a doctrine, and as such they are in a sense beyond criticism. Moreover the values they designate are attractive ones, directed against the narrow intolerance of more restrictive political orders. Why is it, then, that this vision has come so strongly under challenge?

This liberal ethos is not a "philosophy" but a social and political imaginary which draws upon a more or less coherent set of philosophical presuppositions derived from the classical liberalisms of Locke and Mill, from the experience of the New Deal, and from the refusal of Stalinism. They include negative liberty; methodological individualism; suspicion of the powers of the state (although also, in postwar U.S. history, an identification with the American state as a source of freedom in the international arena); and support for free-market capitalism, qualified by the 
acceptance of some restrictions on monopoly such as anti-trust regulation. These principles in turn rely upon a particular topography in which the terms market and civil society belong by virtue of their opposition to the state to a "private" sphere which is a site and condition of freedom, and with which the category of culture too comes to be aligned. The historical contingency of this topography is, however, not just unnoticed but I think unnoticeable in liberal thought. Liberalism fails constitutively, not accidentally - to think three modes of historical transformation in the course of the twentieth century:

(I) the transformation of corporations into forces radically transcendent of any one individual will. Liberalism simply has no good way of thinking about the overwhelming force of concentrated and deregulated capital other than as a system error or imbalance, and that means it has no good way of thinking about the complicities between its vision of cultural openness and the forces in the world that make for closure;

(2) the transformation of the state into something more complex and differentiated than the site of sovereignty, such that it may under certain circumstances be available as a vehicle for the protection of individual freedoms, for the regulation of capital, and for the economic protection of those who lose out in the play of market forces - as well as continuing to be under other circumstances and perhaps also under the same circumstances a vehicle for oppression;

(3) the transformation of the subject of citizenship into the mass-mediated and mass-interpellated subject of the culture industries and of the social imaginary of consumption.

The historical consequence of these transformations has been a preservation of the alignment of the market with civil society, but with civil society now functioning as a space of intense regulation (I don't mean "control" but high levels of codification of values and pleasures); conversely, some of the traditional liberal freedoms and particularly the right of access to a public domain of common intellectual, natural and human resources - are now vested in the care of the state. The conceptual apparatus of liberalism, with its privatized understanding of culture and its lack of suspicion towards market forces, has been ill prepared to give an account of a fully commodified culture: Trilling's conception of an adversarial culture standing over against the world of mass norms (a vision which grows more troubled in his later work, especially with his recognition in Beyond Culture of the institutionalization of modernism) ${ }^{4}$ doesn't work after Warhol; nor can it make sense of a public sphere which is mass mediated, other than by a reaffirmation of those values of rationality and citizenship which, rather than being undermined, are simulated by this new form of publicness.

III.

The neoliberal imagination, by contrast, locating its vision of freedom in an expanded realm of economic transactions rather than in a separate realm of culture, 
has less of a problem in this respect in coming to terms with a form of citizenship grounded in consumption rather than in the sphere of political judgment. Let me define neoliberalism, briefly and schematically, as the nexus of a libertarian economics, an anti-statist politics, and a psychology of interest-governed behavior, which together provide, as Gary Becker puts it, a "unified framework for understanding all human behavior." 5 This framework, deriving philosophically from the libertarian thought of Hayek, Friedman, Nozick, Posner, and others, became entrenched (often in highly distorted forms) in the years of the Reagan and Thatcher regimes, both at the level of the state and in the major international financial bureaucracies. Its version of human selfhood doesn't need to be true or deep as long as it works, and it can incorporate quite complex notions of "interest" (or utilitymaximization), including interests in behaving irrationally, as well as quite complex forms of cost-benefit accounting which would, in principle, include social and environmental costs and benefits. ${ }^{6}$ It thus proposes a notion of choice which is in one sense radically expanded (since it refuses to differentiate between economic, cultural, and political choices, or between "market" and "nonmarket" transactions), but is at the same time drastically impoverished by its methodological decision to exclude from consideration all of those prior infrastructural conditions of existence of markets, including not only the question of their legal and bureaucratic institution and maintenance, and the particular categories of property, of contractual obligation, and of personhood which underpin them, but also the fundamental political questions of lack of equality of entrance into markets and the lack of any commensuration between individual persons and incorporated persons.

Now, this voluntarist account of market choice and the laissez-faire value pluralism that accompanies it is closely paralleled by much work in mainstream cultural studies, especially once you strip away the rhetoric of transgression that gives this work its tenuous political point. Simon Frith has argued that the standard move for cultural studies since Adorno has been

to accept the Frankfurt reading of cultural production and to look for the redeeming features of commodity culture in the act of consumption. . . . In British subcultural theory, this reworking took on the particular form of identifying certain social groups with what we might call "positive mass consumption." ... The value of cultural goods could therefore be equated with the value of the groups consuming them - youth, the working class, women, and so forth. ${ }^{7}$

A plurality of communities of value thus constitute the general field of value in such a way that it forms, as John Guillory argues, a plenum standing in for the whole sphere of citizenship and divided in the same way between constituencies, so that equality of representation then becomes the governing political demand, and the subculture rather than the culture the meaningful point of reference. ${ }^{8}$ In some versions, now perhaps rather dated, this is a matter to be sorted out by the politics of contest over canonicity; in others it is left to the market in identities.

\section{IV.}

The core metaphor of liberalism is that of the contract: at once a commercial instrument and an instrument for the imaginary institution of the social. Contracts 
are settled between legal persons, but I have suggested that the methodological individualism of liberalism (as of neoliberalism) makes it difficult for it to think through the social consequences of the difference in kind and in power between individual persons and incorporated persons. That power differential introduces a radical torsion into the representational structure of public space, a matter to which I return later. For the moment, let me stay with the question of what Lyotard calls the differend, the question of commensuration between incommensurate powers or voices. ${ }^{9}$ The difficulties involved in this question are often cast in terms of the philosophical dilemma of axiological (and, by implication, epistemological) relativism. At their core lies, I think, the unease generated by the fiction that is strategically posited by any politically informed relativism: the fiction that, in order to neutralize my own inevitable partiality, I should consider all domains of value to be formally equivalent. This is also the fiction put into place by any democratic electoral system: that, however passionately I may believe in the rightness of one party, I must suspend this belief in order to recognize the formal right of any other political party to win power and, conversely, to accept as politically legitimate the possibility that my party will lose. This suspension of belief, for all its apparent ordinariness in the established democracies, depends upon a complex form of contract and a sophisticated politics of knowledge. ${ }^{10}$

V.

Elaborating upon the complexity of this politics in an essay entitled "The Mass Public and the Mass Subject," Michael Warner writes:

No matter what particularities of culture, race, and gender, or class we bring to bear on public discourse, the moment of apprehending something as public is one in which we imagine, if imperfectly, indifference to those particularities, to ourselves. We adopt the attitude of the public subject, marking to ourselves its nonidentity with ourselves, ${ }^{11}$

The public is thus a space of the suspension of the self such that real differences can be treated as virtualities. It is this suspension that makes possible what I would call the generous indifference that is the hallmark of democratic civility. Warner argues that in Western political thought this nonidentity is characteristically thought as a corruption or alienation of authentic selfhood: thus the print-based mode of republican virtue that Warner explored in The Letters of the Republic, ${ }^{12}$ which posited an unmediated continuity between person and citizen, "was designed exactly to avoid any rupture of self-difference between ordinary life and publicity" (378). But the category of "the public," Warner writes, has nothing to do with such self-transparency. It is a fiction of genericity, and is therefore a rhetorical fact, predicated on a "moment of special imaginary reference" (379); the fiction involved in the division of identity precedes and constitutes public debate.

At this point in its argument, however, Warner's essay itself develops a certain anxiety about that indifference to particularities that marks the moment of the public. This unease is expounded by way of a historical fable: whereas in the public sphere "collectivity has no link to the body and its desires," he says, the parallel historical formation of persons as the subjects of mass consumption comes to offer a 
counterutopia to the public sphere by virtue of its "balance between a collectivity of mass desires and an unminoritized rhetoric of difference in the field of choice among infinite goods" (385). Consumption, that is to say, offers something like an alternative (and "neoliberal") form of citizenship, one that can recognize and valorize difference in a way that an abstract belonging to a commonwealth cannot do. From this moment the political public sphere and mass consumption are at once alternatives and yet increasingly resemble and shape each other: publicness in the West henceforth has to do with iconicity, a rhetoric of embodiment, the display of bodies for the purposes of "admiration, identification, appropriation, scandal, etc.," rather than with the classical "rhetoric of abstract disembodiment" (385); and public figures "increasingly take on the function of concretizing that fantasmatic body image, or in other words, of actualizing the otherwise indeterminate image of the people" (388). There is thus now a tension in the political realm between the generalized abstraction of the public subject in its classical form and "the always inadequate particularity of individual bodies," and it is this tension that generates the contemporary public sphere's dedication to "a violently desirous speculation on bodies" (397).

In Warner's desire to recuperate the embodied particularity of the self there is, I think, something like a vision of the overcoming of that suspension of selfhood that makes publicness possible, a nostalgia for transparency which assumes that the function of the public sphere is or should be the representation of embodied identities. That "violently desirous speculation" is currently at the center of Australian politics in the erotically charged complex of racist and populist doctrines centered on Pauline Hanson; but it is also of course centrally established in the political theater of the United States, not least in the recent extraordinary spectacle of the American Congress and media working out an obsession with the presidential dick at a time of international economic crisis. We know, of course, that there are ways in which this spectacle is not trivial, that it has to do with a spectacularization and embodiment of the political that at once hollows out its content and yet by this very act performs a(nother) politics; it may offend our deepest notions of the dignity of public office, and yet in a curious way by its reinforcement of the separation of the president's two bodies it does nothing but confirm those notions.

Let me propose two theses about this. The first is that the public sphere is constituted in a process of alienation from self-identity (which of course we may in turn want to understand as similarly constituted); and that such a division of the self in the "moment of special imaginary reference" is a proper use of the suspension of belief and passion that allows the fictions of sociality to work. This suspension, let me emphasize, is as ordinary and as trivial a thing as the willingness to hold two contradictory beliefs at the same time, or rather simultaneously to believe and not to believe; and yet it is this moment of paralogic that makes possible any complex coexistence with others.

My second thesis picks up without endorsing it the darker side of Warner's vision of the public sphere: the sense that it has come to be overdetermined by the sphere of commodity consumption and become the site of a fantasmatic identification. This process corresponds of course to the pun that Habermas describes as sliding across the historical continuum of the concept of Öffentlichkeit, a slide from 
the public sphere of rational judgment to the realm of publicity in which politics comes to function as public relations. ${ }^{13}$ Margaret Morse has written powerfully of the difficulty of strengthening genuinely "public" values in a world structured by an "attenuated fiction effect in everyday life" which slowly and pervasively undermines the "sense of different levels of reality and of incommensurable difference between them." The difficulty is that of appealing to traditional notions of civic responsibility and the public space of the agora in the context of "a built environment that is already evidence of dream-work in the service of particular kinds of commerce, communication, and exchange" and of a representational apparatus in which "the public and private worlds outside are distanced ontologically under several other layers of representation." Thus, she writes, "older notions of the public realm and of paramount reality have been largely undermined, and a return to a pre-televisual world of politics, the street, or the marketplace is unlikely." 14

In developing an argument about culture in part by way of an analogy with the public sphere of political judgment, I have assumed, like most theorists of Western modernity since Weber, the separateness of these categories. But if this separation ever fully existed, it no longer does. The ritual humiliation of a philandering president had everything to do with theater, but a theater which is not the opposite or the secondary representation of political action. If we understand this fact by way of a story of historical decline then we will understand nothing: when do we imagine that politics was ever a matter of dispassionate and rational judgment? But thinking about the public sphere as a site of "violently desirous speculation on bodies" doesn't give us a license either to give up on rational debate and on the critical analysis of social interests, or to reduce political action to the working-out of fantasmatic identifications. What it does do is impose a methodological imperative on us not to separate the study of the political from the study of mass culture. This mass culture is no longer, for the most part, a print culture, and it is perhaps this shift from print to image that most distances us from the liberal vision of a common public culture. Yet in either case what is at issue is not precisely a politics of representation but rather a representational politics, at once the display and the deferral of power. Fictions of generality, like "all people should be equal" or "all citizens should speak a common language," are easily filled with an ugly content precisely because they are, of necessity, empty fictions; indeed, Wendy Brown goes so far as to say that "Democracy's lack of a principle of its own means that any principles to which democracy attaches will be inherently antidemocratic." 15 Minoritization is always a potential outcome of democratic generality. But that generality, that abstraction, that fundamental suspension of reference are also what make possible democracy's imperfect benefits: limited justice, limited acceptance of cultural alterity, and the possibility that groups of citizens will refrain from killing each other because of entrenched differences in ways of being and behaving. ${ }^{16}$

\section{Notes}

I This is the revised version of a paper given at a conference on "The Broken Middle: Cultural Studies and the Liberal Imagination," held at the Whitney Humanities Center, Yale University on 25-26 September 1998 . 
2 Paul Willis et al., Common Culture: Symbolic Work at Play in the Everyday Cultures of the Young (Milton Keynes: Open University Press, 1990).

3 Lionel Trilling, The Liberal Imagination: Essays on Literature and Society (London: Mercury Books, I95I), Xv.

4 Lionel Trilling, "On the Teaching of Modern Literature," in Beyond Culture: Essays on Literature and Learning (1965; reprint, Harmondsworth: Penguin, I967), I9-4I.

5 Gary Becker, The Economic Approach to Human Behavior (Chicago: University of Chicago Press, 1976), I4.

6 Cf. Michael J. Trebilcock, The Limits of Freedom of Contract (Cambridge, MA: Harvard University Press, 1993).

7 Simon Frith, "The Good, the Bad, and the Indifferent: Defending Popular Culture from the Populists," Diacritics 221:4 (1991): I03.

8 John Guillory, Cultural Capital: The Problem of Literary Canon Formation (Chicago: University of Chicago Press, 1993), 6-7.

9 Jean-François Lyotard, The Differend: Phrases in Dispute, trans. Georges Van Den Abbeele (Minneapolis: University of Minnesota Press, I988).

I0 This argument is made in a more extended context in my Cultural Studies and Cultural Value (Oxford: Clarendon Press, I995), I52.

II Michael Warner, "The Mass Public and the Mass Subject," in Habermas and the Public Sphere, ed. Craig Calhoun (Cambridge, MA: MIT Press, 1992), 377. Subsequent references are cited parenthetically in the text.

12 Michael Warner, The Letters of the Republic: Publication and the Public Sphere in Eighteenth-Century America (Cambridge, MA: Harvard University Press, 1990).

I3 Jürgen Habermas, Strukturwandel der Öffentlichkeit: Untersuchungen zu einer Kategorie der bürgerlichen Gesellschaft (Neuwied: Luchterhand, I962); Jürgen Habermas, The Structural Transformation of the Public Sphere: An Inquiry into a Category of Bourgeois Society, trans. Thomas Burger (Cambridge, MA: MIT Press, 1989); cf. especially the shift marked in $\$ I 8$, "Vom kulturräsonierenden zum kulturkonsumierenden Publikum."

I4 Margaret Morse, "An Ontology of Everyday Distraction: The Freeway, the Mall, the Television," in Logics of Television: Essays in Cultural Criticism, ed. Patricia Mellencamp (Bloomington: Indiana University Press, 1990), 213.

I5 Wendy Brown, "Democracy's Lack," Public Culture ro:2 (1998): 427.

I6 Cf. Adam Przeworski, Democracy and the Market: Political and Economic Reforms in Eastern Europe and Latin America (Cambridge: Cambridge University Press, 1991), 95. 


\section{University Library}

\section{- M M I E R R V A gateway to Melbourne's research publications}

Minerva Access is the Institutional Repository of The University of Melbourne

Author/s:

FROW, JOHN

Title:

Cultural studies and the neoliberal imagination

Date:

1999

Citation:

Frow, J. (1999). Cultural studies and the neoliberal imagination. Yale Journal of Criticism, 12(2), 423-430.

Publication Status:

Published

Persistent Link:

http://hdl.handle.net/11343/34300 